УДК 811.111

DOI: https://doi.org/10.18524/2307-4604.2018.2(41).151370

\title{
ONYMS IN SOUTH AFRICAN ENGLISH IN AN ECOLINGUISTIC PERSPECTIVE \\ Pilishek S.
}

PhD (Psychology), Associate Professor, Khmelnytsky National University

ORCID 0000-0002-3685-8901

This article deals with the development of the English language in South Africa which can be regarded as a historically extraterritorial language. The aim of the investigation is to consider the influence of the specific ethnic environment on the lexical system of South African English in the eco-linguistic perspective. A special focus is laid on indigenous onyms which are considered as a means of maintaining the nation's identity in the modern globalized society. The analysis was carried out on the basis of the autobiography of Nelson Mandela "Long Walk to Freedom" (1995). The article begins with a brief outline of a historic background for the formation of the South African variant of the English language. Then the researcher singles out the indigenous onyms employed in the text of $N$. Mandela's autobiography and classifies them into anthroponyms, nationality names, names of clans, royal houses, and toponyms, including a wide variety of geographical names. After that the chosen onyms are subjected to the analysis in the eco-linguistic perspective, exemplifying the thesis that SAA is not only an extraterritorial, but also a contact-induced variety of English. Methodologically, this paper is grounded on the theory of language ecology as a framework for the study of language as an open synergetic system actively interacting with its environment. The study shows that the English language is in tough competition with the rest of official and national languages of the Republic, which form the unique linguistic environment of English in South Africa.

Key words: language ecology, linguistic environment, a synergetic system, South African English, Nelson Mandela.

\section{ОНОМАСТИКОН ПІВДЕННО-АФРИКАНСЬКОГО ВАРІАНТУ АНГЛІЙСЬКОї МОВИ: ЕКОЛІНГВІСТИЧНИЙ ПІДХІД Пілішек C.}

кандидат психологічних наук, доцент, Хмельницький національний університет

\begin{abstract}
У статті висвітлюється проблема розвитку англійської мови в Південній Африиці, по відношенню до якої англійська визначається як екстратериторіальна (імпортована) мова. Мета дослідження полягає у встановленні впливу регіонального етнічного середовища на лексичну систему Південно-Африканського варіанту англійської мови (ПАА), що розглядається крізь призму еколінгвістики і лінгвоекології. Особливу увагу приділено автентичним онімам, які, на думку автора статті, виступають одним із засобів збереження національної ідентичності в сучасному суспільстві, що стрімко глобалізується. Матеріалом для аналізу слугувала автобіографрія Нельсона Мандели «Довгий шлях до свободи» (1995), написана мовою ПАА. Вибір автобіографрічного роману в якості матеріалу для дослідження обумовлений низкою чинників, основні серед яких: значущість Н. Мандели у політичному житті ПАР; етнічна приналежність Н. Мандели до африканського племені ко́за, носієм мови якого він є; а також високий рівень володіння англійською мовою в результаті отримання Н. Манделою університетської освіти. Стаття починається $з$ короткого історичного опису формування ПАА. Потім виділяються етнічно забарвлені оніми, які далі класифрікуються на підгрупи антропонімів, назв кланів, королівських домів, а також топонімів з широким спектром географрічних найменувань. Наступний етап представлено аналізом вибірки в еколінгвістичній перспективі. Методологічною платформою
\end{abstract}


дослідження виступає теорія екології мови як концептуально-понятійна основа для вивчення мови в якості відкритої синергетичної системи, яка активно взаємодіє зі своїм оточенням. Проведене дослідження унаочнює той факт, що англійська мова в ПАР співіснує у жорсткій конкуренції з десятьма офріційними і шістьма національними мовами, а також локальними діалектами, які, взяті разом, утворюють унікальне лінгвістичне середовище для Південно-Афрриканського варіанту англійської мови.

Ключові слова: екологія мови, лінгвістичне середовище, синергетична система, Південно-Африканський варіант англійської мови, Нельсон Мандела.

\section{ОНОМАСТИКОН ЮЖНО-АФРИКАНСКОГО ВАРИАНТА АНГЛИЙ- СКОГО ЯЗЫКА: ЭКОЛИНГВИСТИЧЕСКИЙ ПОДХОД Пилишек C. \\ кандидат психологических наук, доцент, Хмельницкий национальный університет}

В статье затрагивается проблема развития английского языка в Южной Африке, по отношению к которой английский определяется как экстратерриториальный (импортированный) язык. Цель исследования cocmoum в выяснении влияния регионального этнического окружения на лексическую систему Южно-Африканского варианта английского языка (ЮАА), рассматриваемого через призму эколингвистики и лингвоэкологии. Особое внимание сосредоточено на исконных онимах, которые, по мнению автора статьи, выступают одним из способов сохранения национальной идентичности в современном, стремительно глобализуюшемся обществе. Материалом для анализа послужила автобиография Нельсона Манделы «Долгая дорога к свободе» (1995), написанная на ЮАА. Выбор автобиографического романа в качестве материала для исследования обусловлен рядом фракторов, основные среди которых: значимость Н. Манделы в политической жизни ЮАР; этническая принадлежность Н. Манделы к африканскому племени ко́за, носителем языка которого он является; а также высокий уровень владения английским языком в результате получения Н. Манделой университетского образования. Статья начинается с краткого исторического описания формирования ЮАА. Затем выделяются этнически окрашенные онимы, которые далее классифицируются на подгруппы антропонимов, названий кланов, королевских домов, а также топонимов, включающих широкий спектр географических наименований. Следующий этап представлен анализом выборки в эколингвистической перспективе. Методологической платформой исследования выступает теория экологии языка как концептуально-понятийная основа для изучения языка в качестве открытой синергетической системы, активно взаимодействующей со своей окружающей средой. Проведенное исследование наглядно демонстрирует, что английский язык в ЮАР сосуществует в жесткой конкуренции с десятью официальными, шестью национальными языками, а также местными диалектами, которые, взятые вместе, образуют уникальную лингвистическую среду для Южно-Африканского варианта английского языка.

Ключевые слова: экология языка, лингвистическая среда, синергетическая система, Южно-Африканский вариант английского языка, Нельсон Мандела.

\section{Introduction}

In the words of Christopher Ehret, languages can be compared to archives, for each language contains many thousands of individual artefacts of the past: "every language contains a wealth of potential information on the history of the people who have spoken it in the past. It remains only for historians to take even more advantage of that store of evidence" (Ehret 2005: 86).

Onyms, or proper names, are rightly considered to be a very important lexical sphere of language, because, together with common names, they reflect cultural traditions and history of a speaking community. 
A very specific place within onyms is taken up by toponyms, or geographical names, such as names of cities, towns, villages, regions, etc. Toponyms bear a historic coloring and traces of peoples' migration processes. It is toponyms that are the least dynamic group as compared with other semantic classes of onyms. However, cases of renaming places (streets, towns, cities), especially those bearing names with a political background, are quite numerous and are regarded as 'toponymic cleansing'. Hence, toponyms may unveil a lot of fascinating facts about the history and cultural traditions of the people who live on this territory.

This article addresses one of the numerous fragments in the historical development of the English language, namely its South African variant ((henceforth SAE). Our aim is to consider the influence of the specific ethnic environment on the lexical system of English in South Africa. Since the problem raised is too complicated to be solved within one research paradigm, the present study suggests an interdisciplinary approach by integrating the methodological frameworks of language ecology, on the one hand, and that of linguistic synergetics, on the other hand. The subject of the investigation is indigenous onyms in the South African variant of the English language. The object is ecolinguistic aspects of the indigenous onyms component in the publicist discourse of SAE. The analysis was carried out on the basis of the autobiography of Nelson Mandela "Long Walk to Freedom" (1995). The purpose of the present article is to consider the role of indigenous onyms in South African English in the eco-linguistic perspective. To achieve the purpose, a number of tasks are to be solved, among them: to outline a historic background for the formation of the South African variant of the English language; to single out and then group indigenous onyms employed in the text of N. Mandela's autobiography; to consider the indigenous onyms in the South African variant of the English language in the eco-linguistic perspective. Methodologically, this paper is based on the theory of language ecology as a framework for the study of language as an open synergetic system actively interacting with its environment.

\section{Results and discussion}

Let us start with a brief historic outline to shed light on the emergence and development of the South African variant of the English language, also called South African English.

The South African variant of the English language can be classified as an extraterritorial language, that is "one that has been transported from its original geographical home to another area" (Lass 2004: 363). It is the English language that was brought from Britain to South Africa in successive waves of settlement starting from the close of the eighteenth century. The first invasion of the British took place in 1795; however, it was a strategic step, without any idea of colonizing the Cape, which had already been occupied by the Dutch since the middle of the seventeenth century. Seven years later the Cape was returned to the Dutch, and only in 1806 the British came to the Cape again to stay there for another six years. It was only in 1819 that British authorities, including parliament, officially decided to start the process of settlement on the territory. The first wave of immigration was in 1820, the second followed twenty eight years later and finally the third wave took place in the last quarter of the nineteenth century. 
In the eco-linguistic context of the present research, of the paramount importance is the origin of English-speaking settlers who came from a variety of regions on the British Isles. The English language of the early modern period was represented by the following five dialects, namely Northern, West Midland, East Midland, Southern, and Kentish. According to R. Lass, the first large English-speaking group of immigrants included more than 5,000 settlers who came from the south-east of the country and the south-east Midlands; there were also people from the West Country and Yorkshire, and some from Scotland and Wales. They were mostly poor rural people who received land grants on the new territory. The second group of immigrants from the British Isles (1848) included men of middle- and upper-class origin, among them being retired officers and young aristocrats whose English was close to the so-called received standard (Lass 2004: 370). Notably enough, the higher social status of southern speakers provided dominance of the standards of their speech in the whole English-speaking community. In the course of time, the linguistic characteristics of the speech of British settlers influenced by a number of encounters with other local speech communities made up the foundation of the new territorial variety of English.

Today, South African English bears certain distinguishing features that can be spotted on each of the language levels - phonemic, morphemic, lexical, and syntactic. Our present concern lies with the lexical level of language with a special focus on indigenous onyms.

The SAE vocabulary is etymologically motley, which is not surprising, if one looks back at its history. Speaking of language and language varieties, Edgar Schneider noted that no language can be monolithic since it comes in many shadings, in varieties and dialects. Similarly, language "varieties include standard languages and national varieties, but also regional, social and ethnic dialects, group-specific language forms, contextually and stylistically defined expressions, and so on, for use in their respective cultural contexts" (Schneider 2011: 18).

A lexical system of a language is but an open synergetic system (Dombrovan 2018: 33), which means that it reflects social, economic, political, technological, scientific, and cultural aspects of the speech community by saving the new notions in the lexical depository. It is one of the most dynamic subsystems of language, prone to the impact of its environment.

Environment of a language is determined by the interactions of the latter with other languages of the community. Einar Hagen defines language ecology as the study of interactions between any given language and its environment; more than that - the true environment of a language is the society that uses it as one of its codes (Haugen, 1972).

Republic of South African is unique as to the scope of languages its community employs. It is to be called multilingual, since there are as many as eleven (!) official languages in the country, counting out six national languages, a number of local dialects and languages of tribal minorities. The data for 2011 are taken from 'Statistics South Africa" and given in Figure 1 below. 
Number of speakers per language

in South Africa (2011)
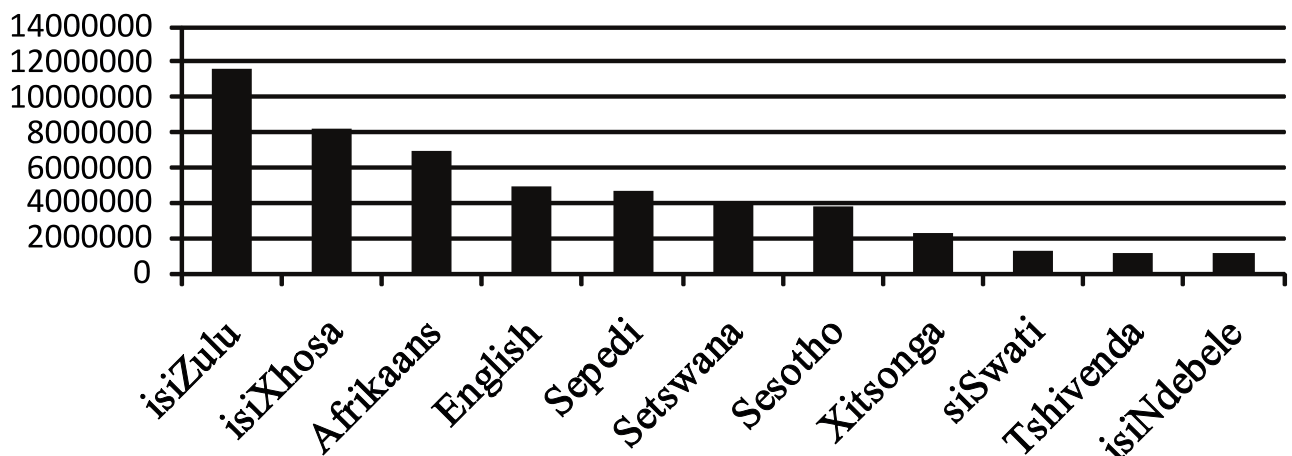

Fig.1. Official languages in Republic of South Africa and the number of their speakers

As is seen in Fig. 1, in 2011 the English language was used as an official language by $4,892,623$ speakers out of $51,800,000$ citizens of the Republic (which equals to $9.5 \%$ ), following isiZulu, isiXhosa and Afrikaans. Unfortunately, this data does not reveal the number of native speakers of English or the number of people using it as a second language. Recent research shows that "English is used in South Africa as a native language by some whites of British descent and the younger generations of South African Indians, and as a second language by others, namely the black population, the older generations of South African Indians, and the whites of Dutch descent, the Afrikaners" (Kamwangamalu 2006: 162).

According to the data of 2011 given by SAlanguages.com, English is chosen as a language for home communication by approximately the same number of people, to be more precise by $9.6 \%$ of South Africans (see Figure 2).

\section{Home Language in South Africa (2011) ,\%}

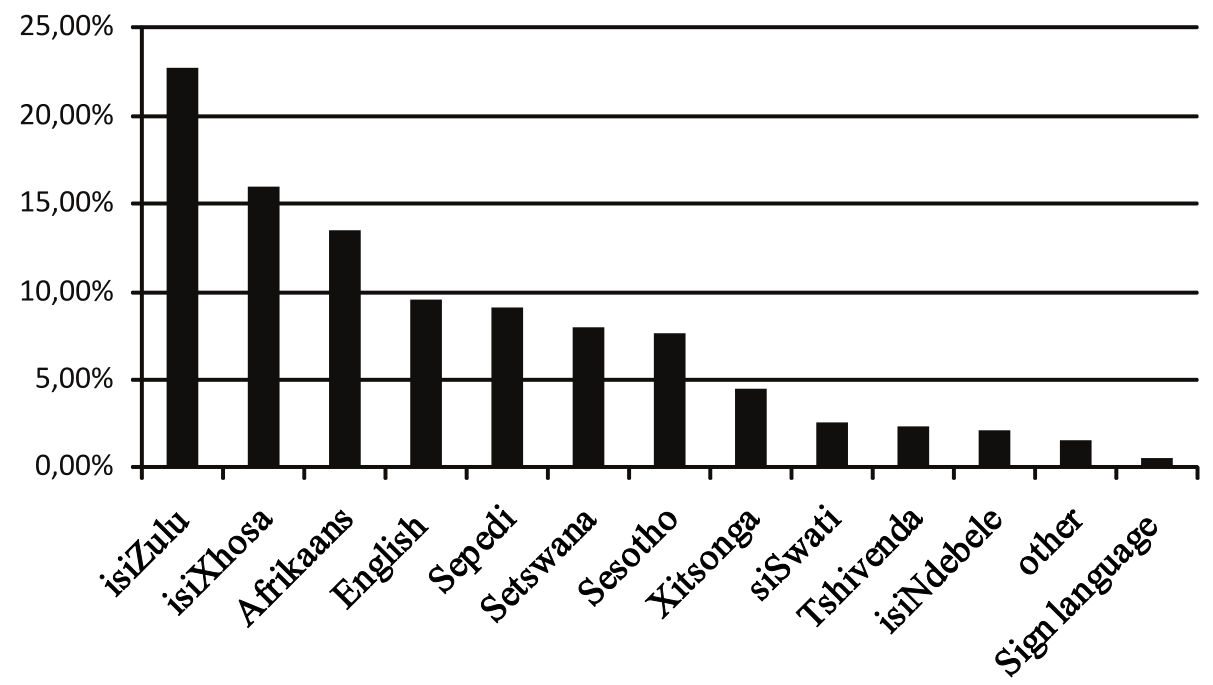

Fig.2 Home languages in South Africa 
The data of Fig. 1 and Fig. 2 suggest that nowadays the English language is in tough competition with the rest of official and national languages of the Republic. The latter form the unique linguistic environment of English in South Africa, or put differently, the English language ecology in the mentioned area. The impact of the environment is so great that researchers refer to SAE in the plural number - South African Englishes (see, e.g. Kamwangamalu 2006: 158).

A valuable resource for the present study is the autobiography of Nelson Madela, Long Walk to Freedom. Nelson Mandela (1918-2013) was an outstanding politician in South Africa, the Nobel Peace Prize Laureate (1993), and an antiapartheid activist who was imprisoned for 27 years for his anti-racist politics. In 1994 Mandela became the first black president of the Republic. N. Mandela is seen as Africa's greatest freedom symbol; his birthday, 18 July, is the national holiday in the country.

$\mathrm{N}$. Mandela's mother tongue was isiXhosa (isi- is a prefix meaning 'language'), but he was lucky to learn English and receive a university degree. His Autobiography is written in SAE with a wide scope of indigenous words, including onyms which, for the purpose of the present investigation, were singled out and classified into the following groups:

(1) Anthroponyms, or names of people. They are especially many in the first chapters of the book, introducing early years of the author's life. Among them are Rolihlahla (Nelson's middle name, meaning 'troublemaker' in Xhosa), Tatomkhulu (Nelson's pet name, meaning 'grandpa'), Gadla Henry Mphakanyiswa (Nelson's father's name), Nosekeni Fanny (Nelson's mother's name), Baliwe, Notancu, and Makhutswana (his sisters' names), King Zwide, Ngubengcuka, Mthikrakra, Ngangelizwe, Sabata, Jogintaba, Dabulamanzi, Melithafa, etc. For instance,

At the ceremony, I was given my circumcision name, Dalibunga, meaning "Founder of the Bunga," the traditional ruling body of the Transkei. To Xhosa traditionalists, this name is more acceptable than either of my two previous given names, Rolihlahla or Nelson, and I was proud to hear my new name pronounced: Dalibunga. (Part 1, Chapter 4).

However, N. Mandela does not restrict his writing to that of a personal biography. In fact, his book reveals the history of a great nation. Mandela relates a fascinating story about his great ancestors whose names he feels pride to mention. For instance:

Mthikrakra, the eldest son of the Great House, succeeded Ngubengcuka and amongst his sons were Ngangelizwe and Matanzima. Sabata, who ruled the Thembu from 1954, was the grandson of Ngangelizwe and a senior to Kalzer Daliwonga, better known as K. D. Matanzima, the former chief minister of the Transkei - my nephew, by law and custom - who was a descendant of Matanzima. The eldest son of the Ixhiba house was Simakade, whose younger brother was Mandela, my grandfather. (Part 1, Chapter 1).

(2) Nationality names and names of tribes, such as The Thembu tribe, Xhosas, Basothos, the Nguni people, the Madiba clan, a descendant of the Ixhiba house, etc. For example: 
I am often addressed as Madiba, my clan name, a term of respect (Part 1, Chapter 1);

With very few exceptions, Africans at the time did not enjoy private title to land in South Africa but were tenants paying rent annually to the government. (Part 1, Chapter 2).

Mandela gives details of genealogical affinity of tribes, as in:

The Nguni can be divided into a northern group - the Zulu and the Swazi people - and a southern group, which is made up of amaBaca, amaBo myana, amaGcaleka, amaMfengu, amaMpodomis, amaMpondo, abeSotho, and abeThembu, and together they comprise the Xhosa nation. (Part 1, Chapter 1).

The ama- prefix stands for 'people, clan'. To refer to one representative of the clan or tribe the prefixes um- or abe- are used, e.g. umZulu, umXhosa, abeThembu. For ethnic groups of north districts the prefix mu-/mo- is employed, e.g. muVenda (meaning 'a man of Venda clan'), moPedi ('a man of Pedi clan'). The collective meaning is expressed by vha-/ba- prefixes. Thus, VhaVenda means 'Venda clan', also BaPedi means 'Pedi clan'. Mandela also uses the English ending $-s$ to refer to the plural number of tribesmen, e.g. Zulus , Khosas, Pedis, Vendas.

(3) Names of royal houses, such as the Great House, Left Hand House and others, as in:

Ngubengcuka, one of the greatest monarchs, who united the Thembu tribe, died in 1832. As was the custom, he had wives from the principal royal houses: the Great House, from which the heir is selected, the Right Hand House, and the Ixhiba, a minor house that is referred to by some as the Left Hand House. It was the task of the sons of the Ixhiba or Left Hand House to settle royal disputes. (Part 1, Ch.1);

$<\ldots>$ my father had four wives, the third of whom, my mother, Nosekeni Fanny, the daughter of Nkedama from the amaMpemvu clan of the Xhosa, belonged to the Right Hand House. (Part 1, Ch. 1).

Notably enough that wives of the kings, besides their first names, can be referred to as connected to a certain royal house, e.g.

Each of these wives - the Great Wife, the Right Hand wife (my mother), the Left Hand wife, and the wife of the lqadi or support house had her own kraal. (Part 1, Ch. 1).

(4) Toponyms, or place names. They are especially numerous in the first chapter of the Autobiography, e.g.

I was born on the eighteenth of July, 1918, at Mvezo, a tiny village on the banks of the Mbashe River in the district of Umtata, the capital of the Transkei. (Part 1, Chapter 1);

The Transkei is eight hundred miles east of Cape Town, five hundred fifty miles south of Johannesburg, and lies between the Kei River and the Natal border, between the rugged Drakensberg mountains to the north and the blue waters of the Indian Ocean to the east. (Part 1, Chapter 1).

Among the geographical names we come across names of mountain chains and peaks (the Drakensberg mountains; the Reef, the great ridge of gold- 
bearing rock), river names (the Mbashe River known as Tyhalarha), names of settlements (Mqhekezweni, the provisional capital of Thembuland; Qunu), as well as administrative units (the protectorates of Basutoland, Swaziland, and Bechuanaland), and names of educational establishments (Clarkebury). It is hardly possible to find in the first chapters of Autobiography a sentence without any onym, e.g.

Clarkebury was a Thembu college, founded on land given by the great Thembu king Ngubengcuka; as a descendant of Ngubengcuka, I presumed that I would be accorded the same deference at Clarkebury that I had come to expect in Mahekezweni. But I was painfully mistaken, for I was treated no differently than everyone else. No one knew or even cared that I was a descendant of the illustrious Ngubengcuka. (Part 1, Ch.5).

The wide use of indigenous onyms in SAA proves that the latter is not only an extraterritorial, but also a contact-induced variety of English. The specific ecology of English in SAR, determined by the social stratification of the latter, contributes to certain distinguishing features of SAA. Our investigation has supported E. Schneider's observation that language contact has been ubiquitous in the history of English and has shaped the newly emergent varieties of the language in a fundamental way (Schneider 2013: 148).

\section{Conclusion}

To sum up, onyms make up a considerable layer in SAE. Being a kind of link between the past and the present and even the future, they are an important part of the social, historical and cultural spheres of a nation. More than that, onyms can be seen as a means of maintaining the nation's identity in the modern globalized society.

Our research shows that ecology of a language (in this case - SAE) is determined by a variety of factors, language contacts being the most important one. SAE co-exists with a great many other languages of local ethnic groups in an extremely multilingual community of the area. As a result, it bears traces of the contacts. Moreover, SAE should be regarded as a result of the ever going process of language contacts. The 'intrusion' of indigenous onyms is one of the consequences related to the vocabulary of SAE. Others are still awaiting further research.

\section{References}

Ehret, Christopher (2005). Writing African History from Linguistic Evidence. In Writing African History, ed. J. E. Philips. Rochester, NY: University of Rochester Press, pp. 86-110.

Ehret, Christopher (1998). An African Classical Age: Eastern and Southern Africa in World History, 1000 B.C. to A.D. 400. Charlottesville: University of Virginia Press.

Haugen, Einar (1972). The Ecology of Language. Stanford University Press, Stanford, CA.

Dombrovan, Tetiana (2018). An Introduction to Linguistic Synergetics. Cambridge Scholars Publishing.

Kamwangamalu, Nkonko M. (2006). South African Englishes. In: The Handbook of World Englishes /Ed. by Braj B. Kachru; Yamuna Kachru, Cecil L. Nelson. Blackwell Publishing Ltd. PP.158-170.

Lass, Roger (2004). South African English. In: Legacies of Colonial English: Studies in transported dialects /Ed. by Raymond Hickey. Cambridge: Cambridge University Press. PP. 363386.

Mandela, Nelson (1995). Long Walk to Freedom: The Autobiography of Nelson Mandela. 
PILISHEK S. ONYMS IN SOUTH AFRICAN...

Boston-New York-London: Little, Brown and Co.

Ricquier, Birgit (2016). Historical Linguistics: loanwords and borrowing. In Oxford Research Encyclopedia of African History. Online Publication Date: Jul 2018. DOI:10.1093/ acrefore/9780190277734.013.362

Schneider, Edgar W. (2011). English Around the World: An Introduction. Cambridge: Cambridge University Press.

Schneider, Edgar W. (2013). English as a contact language: the "New Englishes". In English as a Contact Language / Ed. by Daniel Schreier and Marianne Hundt. Cambridge, N.Y., Melbourne, etc. Cambridge University Press. PP. 131-148.

South African Languages. Mode of access: http://www.salanguages.com/stats.htm

Statistics South Africa: Mode of access: http://www.statssa.gov.za

Стаття надійшла до редакції 9.10.2018 p. 